\title{
SOME IMPORTANT FACTORS AFFECTING FERTILITY IN SHEEP
}

\author{
M.P.Petrovic ${ }^{1}$,V. Caro Petrovic ${ }^{1}$, D. Ruzic Muslic ${ }^{1}$, N. Maksimovic ${ }^{1}$, Z. \\ Ilic $^{2}$, B. Milosevic ${ }^{2}$, J.Stojkovic ${ }^{2}$ \\ ${ }^{1}$ Institute For Animal Husbandry, Belgrade, Serbia \\ ${ }^{2}$ University of Pristina, Faculty of Agriculture, Kopaonicka bb, 38219 Lesak, Serbia \\ Corresponding author: milanppet@yahoo.com \\ Review paper
}

Abstract: Efficiency of sheep production is conditioned by fertility. According to some authors number of offspring obtained per lambing is more important than gain of weight. Genetic relationships involving reproductive traits were seldom studied. Reproductive traits have low heritabilities, a discrete phenotypic expression, and are expressed only in sexually mature ewes leading to low selection intensities and long generation intervals. Documentation of realized selection response is also often complicated by the low heritabilities of fertility traits. Existence of a major gene affecting prolificacy had been suggested and at that time there were many sceptics who strongly doubted that a trait as complex as reproduction could be profoundly influenced by a single gene. Major genes affecting prolificacy in sheep was founded. A mutation in the bone morphogenetic protein 15 gene (BMP15, also known as $G D F 9 B)$ responsible for high prolificacy in Inverdale sheep had been discovered and evidence of segregating major genes was being reported from flocks around the world. Development of gene mapping techniques, and locating alleles that are responsible for the fertility of sheep began a new chapter in predicting and controlling the fertility of sheep. The beneficial effects of nutrition on reproduction in sheep are well known. This procedure is known as flushing. The effect of Body Condition Score (BCS), before mating, during mating and after mating period, on reproductive efficiency of different breeds of sheep in the different rearing systems were studied. The farm manager has the ability to control or at least to manipulate the factors that have an impact on fertility.

Keywords: sheep, fertility, genetics, nutrition, management

\section{Introduction}

Fertility is one of the most important parameters of sheep productivity, the number of offspring obtained per lambing is a good indicator, and according to 
some authors (Petrović, 2000) it is more important than gain of lambs. This means that biological efficiency of sheep in regard to meat, milk and wool production is conditioned by fertility ( Notter et al., 2000). Low fertility is a continuing problem in Australian flocks (Scaramuzzi and Lindsay 1986).

Success in selection of sheep in regard to their fertility greatly depends on genetic variability of reproductive components (Petrović et al., 1997, 2001, 2002, 2007). Heritability for onset of puberty is low and within the interval of 0,1 to 0,26 (Petrović, 2000). Range or norm of ovulation in sheep is still great challenge for the science, regardless of the fact that it is generally known that it is under control of larger number of genes, i.e. its poligeneous character. Activities directed to gene identification responsible for this trait are in progress (Galloway et al., 2000, Davis et al., 2001, Grant et al., 2001, Wilson et al., 2001).

For traits of sheep fertility, of great importance is also embryonic mortality, which is especially present during first four weeks of pregnancy, when $20-30 \%$ of fertilized egg cells can be lost, and which is in negative correlation with ovulation rate (Perez et al., 1994).

Feeding of sheep is also one of the most important factors that influence the fertility of sheep. There are many controversies about it, how best to prepare a sheep for mating. Flushing is understood as the rapid increase in ovulation rate of ewes receiving a nutrient supplementation before mating. Branca, et al., 2000. Lassoued et al. (2004), showed important interactions between genotype and level of nutrition. In this sense, in highly prolific ewes like D'Man breed, higher levels of nutrition prior to and during mating were associated with improved reproductive performance, but in low prolific breeds such as Queue Fine de l'Ouest, neither ovulation rate nor lambing rate were affected by the dietary treatment. In a recent work by Fukui et al. (2010) body weight did not significantly affect fertility.

Oestrus in the majority of sheep has a seasonal character, which means that the sheep exhibit sexual glow during the summer from Jun to September. It is linked to many as genetic and external factors (Petrović, 2000). Very often it is associated with climatic and seasonal conditions over which the producer has little control. On the other hand there are numerous production factors which influence fertility and which are amenable to management.

In this paper we would like to touch about the following factors that may affect the fertility of sheep:

- Genetics

- Nutrition

- Management

\section{Genetics and fertility}

Number of offspring and growth of lamb, indicated by body weights and rate of gain at different phases of growth are among the most economically 
important and easily-measured traits. Knowledge on the particular trait and phase of the animal's growth upon which to base selection is therefore of utmost importance. Genetics/heredity affects the fertility of farm animals in a variety of ways. Some animals may be genetically infertile. Genetic differences do exist between different breed and types of sheep. Romanov sheep commonly have lambing percentages of 250 while Pramenka tend to have lambing percentages of close to 110 . Genetic mutations can occur which can produce infertility. They can also give rise to abnormal development in embryos so much so that the young fail to develop properly and cause fetal death or atrophy. These are called lethal factors.

Genetic relationships involving reproductive traits were seldom studied. Reproductive traits have low heritabilities, a discrete phenotypic expression, and are expressed only in sexually mature ewes leading to low selection intensities and long generation intervals. Documentation of realized selection response is also often complicated by the low heritabilities of fertility traits. Based on the research of Al-Shorepy and Notter (1997), selection for fertility in an annual fall lambing system resulted in increases in estimated breeding value (EBV) for fertility and in correlated increases in fall litter size. Pedigree estimates of EBV for fertility were positively associated with future performance, and fertility EBV was significantly associated with future fertility. These results suggest that performance in fall lambing can be improved by selection.

Piper and Bindon (1980) reported the possibility that fecundity of the Booroola Merino as result from the action of a single major gene or closely linked group of genes affecting ovulation rate. This was the first time that the existence of a major gene affecting prolificacy had been suggested and at that time there were many sceptics who strongly doubted that a trait as complex as reproduction could be profoundly influenced by a single gene. Two decades later, some groups of researchers (Mulsant et al., 2001., Souza et al., 2001., Wilson et al., 2001), simultaneously discovered that the inheritance of prolificacy observed in the Booroola Merinos was the result of a mutation in the bone morphogenetic protein $1 \mathrm{~B}$ receptor $(B M P R-1 B)$. Meanwhile the notion of major genes affecting prolificacy in sheep was no longer regarded as genetic heresy. A mutation in the bone morphogenetic protein 15 gene (BMP15, also known as GDF9B) responsible for high prolificacy in Inverdale sheep had been discovered by Galloway et al. [16] and evidence of segregating major genes was being reported from flocks around the world.

The development of molecular genetics and gene mapping techniques he began in a period of locating themselves alleles that are responsible for the fertility of sheep (Table 1). Thus began a new chapter in predicting and controlling the fertility of sheep. 
Table 1. Some known and putative major genes for prolificacy in sheep (Davis, 2004)

\begin{tabular}{|l|c|c|c|c|}
\hline Gene & Name & Allele & Chr & Breed \\
\hline$B M P R-1 B$ & Booroola & $F e c B B$ & 6 & Merino \\
\hline$B M P 15$ & Inverdale & $F e c X I$ & $\mathrm{X}$ & Romney \\
\hline$B M P 15$ & Hanna & $F e c X H$ & $\mathrm{X}$ & Romney \\
\hline$B M P 15$ & Belclare & $F e c X B$ & $\mathrm{X}$ & Belclare \\
\hline$B M P 15$ & Galway & $F e c X G$ & $\mathrm{X}$ & Belclare and Cambridge \\
\hline- & Woodlands & $F e c X 2 W$ & $\mathrm{X}$ & Coopworth \\
\hline- & Lacaune & $F e c L L$ & 11 & Lacaune \\
\hline
\end{tabular}

Selection for increased fertility of sheep causes more egg cells to be shed per ovulation and if a ewe normally ovulates a large number of egg cells the chances will be good that, when conditions are unfavorable. Sheep will then have a chance to at least one cell can be fertilized and thus resulted in offspring. Use of physiological quantitative parameters in sheep improvement in increase of fertility is one of the procedures which can lead to success in sheep selection on fertility (Petrovic et al., 2007).

Favorable environmental conditions like good feeding and management have the same influence, as selection, and the results attained in this manner are faster and more spectacular. Seeing that more multiple births occur under favorable conditions it is a very good method to identify ewes and rams which have genetic potential for fertility.

\section{Nutrition and fertility}

The beneficial effects of nutrition on reproduction in sheep are well known (Forcada and Abecia, 2006). In particular, nutrition is one of the main factors affecting ovulation rate. Generally sheep will be at grass for half of the year, however during winter or at lambing they may be housed or given extra feed at grass. It is important to get the nutrition right to prevent loss of body condition or problems at lambing. Poor nutrition may cause irregular cycles in females, reduced ovulation, weak offspring, and pregnancy toxemia or reduced twinning. In males poor nutrition may reduce sperm quantity and quality. Abadjieva et al.,(2011) informed that the fertility is determined by a multi-hormonal effect, included not only sex and gonadotropic hormones, but also "metabolic" hormones. A functional defect in any of the components of this hormonal complex directly affects reproduction. They also add that new scientific data confirms the strictly dependence of reproduction on energy sources and metabolic state and shows their signaling ways. The both have a big importance for good fertility.

The amount of food given to ewes immediately before fertilization is also of considerable importance. Experiments have shown that, if at that stage, given to 
ewe a generous plane of nutrition she is likely to shed more eggs than normal. This results in a higher lambing percentage by increasing the number of twin births. This procedure is known as flushing. Special attention must be paid to mineral and vitamin supplement.

Effect of Body Condition Score (BCS), live weight (static effects) and changes in BCS and live weight (dynamic effects) before mating, during mating and after mating period, on reproductive efficiency of different breeds of sheep in the different rearing systems were studied ( Cam et al., 2010, Aliyari et al., 2012). Most of researchers have reported that, the absolute effects of BCS and live weight than their variations have greater impact on sheep reproduction efficiency, which suggest the importance of breed and interactions with nutritional and physiological conditions and its impact on reproduction efficiency (Gunn, 1983; Koycegiz et al., 2009). A correlation exists between BCS, live weight and amount of reserving body fat (Oregui et al., 1997). Also to prediction of adult weight of sheep with different genotypes, BCS is suitable (Zygoyiannis et al., 1997).

Live weight is a combination of skeleton size and BCS and it's not a good representative to evaluate the reproductive efficiency. Adults weight is affected by factors such as skeleton scheme (body size), fullness or hunger trap (filled or empty digestive tract) or being wet wool (Demirel et al., 2004). Many researchers have reported that, fertility affected by BCS (Doney et al., 1982; Guerra et al., 1972; Gunn, 1983; Koyuncu, 2005; Madani et al., 2009). Garcia et al. (2002) showed the significant effect of body to initiation of lambs' puberty.

Effect of Body Condition Score, on some reproductive performance of Afshari ewes was studied by Aliyari et al., 2012 (table 2).

Table 2. Effect of BCS on Mean \pm SE reproductive traits (Aliyari et al., 2012)

\begin{tabular}{|l|c|c|c|c|c|}
\hline Trait & $\mathrm{BSC}(2)$ & $\mathrm{BSC}(2.5)$ & $\mathrm{BSC}(3)$ & $\mathrm{BSC}(3.5)$ & $\pm \mathrm{SE}$ \\
\hline Lamb born joined ewes & 1.24 & 1.30 & 1.40 & 1.05 & 9.60 \\
\hline Kg lambs born/ joined ewes & 6.70 & 6.71 & 7.40 & 5.54 & 0.45 \\
\hline No of mating conception & 1.36 & 1.20 & 1.15 & 1.20 & 0.09 \\
\hline Birth weight (kg) & 5.36 & 5.15 & 5.34 & 5.29 & 0.10 \\
\hline Weaning weight (kg) & 32.50 & 32.83 & 33.41 & 34.87 & 0.86 \\
\hline Pregnancy duration (day) & 151.72 & 151.31 & 151.18 & 151.05 & 0.15 \\
\hline Ewe conceived at 1 $1^{\text {st }}$ estrus & 78.00 & 82.00 & 86.00 & 86.00 & 9.60 \\
\hline Kg lambs born/lambing & 6.99 & 7.10 & 7.56 & 7.02 & 0.38 \\
\hline
\end{tabular}

The effect of nutrition on ovulation rate is more evident over a period and when the nutritional treatments are done in the transitional period between anoestrus (seasonal or lactational) and the breeding season. Nutrition has a smaller influence on sexual activity than on ovulation rate. In contrast, the modification of reproductive seasonality in ewes that have a moderate level of fat reserves using the level of nutrition as the only management tool seems to be difficult. 
In the Mediterranean environment, however, it is possible to overcome the regulating effect of photoperiod on reproductive seasonality in ewes that have a moderately high level of fat reserves. Results of Forcada and Abecia (2006) show a consistent reduction $(P<0.05)$ in the duration of seasonal anoestrus in ewes maintained from November to September at a constant, moderately high body condition score (BCS-2.9) when compared to females having a lower body condition score (BCS-2.3) (Fig. 1).

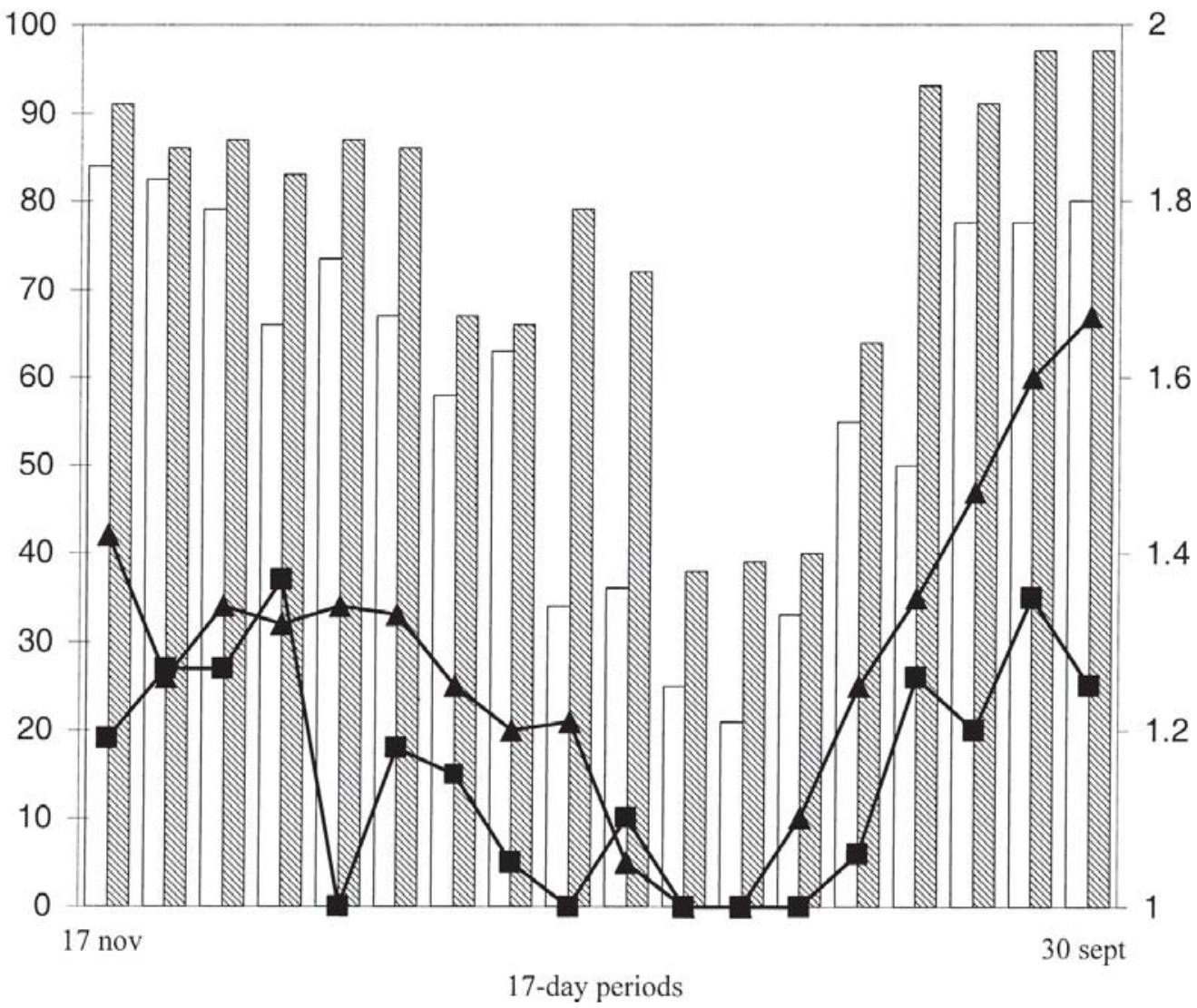

Figure 1. Oestrous activity and ovulation rate of Rasa Aragonesa ewes maintained at two constant

levels of body condition score (BCS) throughout the year: moderately high (2.8) (filled bars and respectively) and moderately low (2.3) (white bars and respectively) (Forcada et al., 2006)

Signaling mechanisms for the provision of nutritional feedback from peripheral tissues to the hypothalamus include leptin and insulin, since their 
secretion is influenced by both body condition (BCS) and food intake in sheep (Marie et al. 2001). Both hormones are implicated in nutritional modulation of reproduction (Blache et al. 2000a) and in appetite/bodyweight regulation (Schwartz et al. 2000).

Body reserves (long-term) and food intake (short-term) both contribute nutritional feedback to the hypothalamus. Reproductive neuroendocrine output $(\mathrm{GnRH} / \mathrm{LH})$ is stimulated by increased food intake and not by high adiposity in sheep, but it is unknown whether the appetite regulating hypothalamic neurons show this differential response.

The amount of food given to the pregnant mother also influences birth weight of offspring and heavier offspring have a better chance of surviving. Conversely, the undersized new born animal has less chance of surviving and frequently dies in the first few days following birth. Such an animal is less able to maintain its body temperature and may die quickly if born in cold weather. If overfed, the pregnant animal may suffer difficulties in birth which could also lead to death of either the offspring or mother or both. Under nutrition in late pregnancy, particularly in ewes carrying twins may cause pregnancy toxemia. This has given rise to the practice of steaming up. Steaming up is feeding technique where females are put on a rising plane of nutrition in the latter stage of pregnancy. It increases birth weight and milk production.

\section{Management and fertility}

The farm manager has the ability to control or at least to manipulate the factors that have been discussed above. Different ewe farms have different management practices and this may have an impact on fertility. Examples of how farmers control or manipulate these factors include:

- Selection of both male and female animals on the basis of their ability to produce offspring

- Ensuring the correct proportion of male to female animals if using natural mating

- Selecting animals suited to the environment

- Providing correct nutrition for the stage of production of the animals

- Selecting paddocks that minimize the detrimental effects of environmental factors for newly born animals

- Use of strategic worm control program

- Use of a suitable vaccination program 
The significant effect of the farm management has been described in several studies (Anel, et al., 2005, Paulenz, et al., 2002). Planning of intervals between lambings, choosing females to inseminate might slightly improve the fertility results (David et al. (2008). The need for a resting period for the ewe after lambing to allow uterine involution is well known. However, sometimes the increasing reproductive rate imposed by the demanding production system involves short resting periods from lambing to AI, which affects fertility in a negative way. According to Bodin et al. (1999), reducing the lambing-AI interval to below 40-50 days induces a significant decrease in fertility, even after natural mating. Most authors recommend not inseminating ewes any sooner than 50 days post-partum (Anel, et al., 2005). High body temperatures produced in rams by high summer temperatures is a cause of poor quality semen. High temperatures can also affect mating with reduced sexual activity. Conception rate is also reduced. This affects the number of offspring born. Reproductive planning (intervals between lambings, season, age of first mating, AI technique, etc.) and animal handling (feeding, health, preparation of AI lots, etc.) have a great effect on fertility results (Anel, et al., 2005). David et al. (2008), using a joint model combining two main traits, one relative to female and the other relative to the male, reported that the main variation factors of AI success were relative to non-sex-specific effects and to female effect, suggesting that choosing females to inseminate might slightly improve the AI results.

\section{Conclusion}

Based on the results presented by various authors, it could be concluded that the fertility of sheep is very complex property, and because of its importance in achieving success in sheep production, it has been studied from various aspects. Reproductive traits have low heritability, discrete phenotypic expression and are expressed only in sexually mature ewes, leading to the selection of low intensity and long generational intervals. The use of certain physiological parameters in the selection can contribute to the success. Major genes affecting fertility have been found in many sheep around the world. The development of techniques to map the location of genes and alleles that are responsible for the fertility of sheep, open a new chapter in predicting and controlling the fertility of sheep. The beneficial effects of nutrition on reproduction in sheep are well known. Influence of body condition score (BCS), before mating, during mating and after mating on the reproductive efficiency of different breeds of sheep also studied many authors mentioned here. Farmer through the management has the ability to control, or at least manipulate factors that influence the fertility, which is also presented in this review paper. Despite the many factors that affect fertility of sheep, it appeared that 
the factors of genetics, nutrition and management has major role in influencing the fertility and the final successful sheep production.

\section{Važniji faktori koji utiču na plodnost kod ovaca}

M.P.Petrović, V.Caro Petrović, D. Ružić Muslić, Z. Ilic, B. Milosević,, J.Stojković, N. Maksimović

\section{Rezime}

Efikasnost proizvodnje ovaca je uslovljena plodnošću. Prema nekim autorima broja potomaka dobijenih po jagnjenju je važnije od prirasta i mase tela. Genetski uticaji koji uključuju reproduktivne osobine se retko izučavaju. Plodnost ovaca ima nizak heritabilitiet, diskretnu fenotipsku ekspresiju, a izražena je samo u seksualno zrelih ovaca, što dovodi do niskog intenziteta selekcije i dugih generacijskih intervala. Otkriće major gena koji utiču na plodnost je u to vreme otkrilo mnogo skeptika koji su snažno sumnjali da takav kompleks reprodukcije može biti duboko pod uticajem jednog gena. Glavne geni utiču na plodnost kod ovaca i ovnova. Mutacija u koštanoj morfogenetsko proteina 15 gena (BMP15, takođe poznatom kao GDF9B) otkrivena je kod mnogih ovaca širom sveta, kao dokaz segregacije major gena. Razvojem tehnika mapiranja gena i lociranja alela koji su odgovorni za plodnost ovaca, počeolo je novo poglavlje u predviđanju i kontrolisanju plodnosti ovaca. Povoljni efekti ishrane na reprodukciju u ovaca su dobro poznati. Ovaj postupak je poznat kao flushing, pred oplodnju. Uticaj kondicije tela (BCS), pred parenje, tokom parenja i posle parenja na reproduktivnu efikasnost različitih rasa ovaca u različitim podizanju sistema su takođe proučavali mnogi ovde pomenuti autori. Farmer putem menadžmenta ima mogućnost da kontroliše, ili bar da maniupulate faktorima koji imaju uticaj na plodnostovaca, a što je takođe predstavljeno u ovom preglednom radu.

\section{References}

ABADJIEVA D., SHUMKOV K., KISTANOVA E., KACHEVA D., GEORGIEV B. (2011):

Opportunities for the improvement of the reproductive performances in female animals .Biotechnology in animal husbandry 27, 365-372.

ALIYARI D., MOEINI M.M., SHAHIR M.H., SIRJANI M.A.(2012): Effect of Body Condition Score, Live Weight and Age on Reproductive Performance of Afshari Ewes. Asian Journal of Animal and Veterinary Advances, 7, 904-909. 
AL-SHOREPY S. A., NOTTER D. R. (1997): Response to Selection for Fertility in a Fall-Lambing Sheep Flock. J. Anim. Sci. 75:2033-2040.

ANEL L., KAABI M., ABROUG B., ALVAREZ M., ANEL E., BOIXO J. C., DE LA FUENTE L. F., DE PAZ P.(2005): Factors influencing the success of vaginal and laparoscopic artificial insemination in Churra ewes: a field assay. Theriogenology, 63, 4, 1235-1247.

BLACHE D., CHAGAS L.M., BLACKBERRY M.A., VERCOE P.E., MARTIN G.B.(2000): Metabolic factors affecting the reproductive axis in male sheep. Journal of Reproduction and Fertility. 120, 1-11.

BODIN L., ELSEN J. M., HANOCQ E., FRANCOIS D., LAJOUS D., MANFREDI E., MIALON M. M., BOICHARD D., FOULLEY J. L., SANCRISTOBAL-GAUDY M., TEYSSIER J., THIMONIER J., CHEMINEAU P.(1999): Genetics of reproduction in ruminants. Productions Animales, 12, 2, 87100.

BRANCA A., MOLLE G., SITZIA M., DECANDIA M., LANDAU S.(2000): Short-term dietary effects on reproductive wastage after induced ovulation and artificial insemination in primiparous lactating Sarda. Animal Reproduction Science, 63, 1-2, 0378-4320.

CAM M.A., OLFAZ AND M., SOYDAN E.(2010): Body measurements reflect body weights and carcass yields in karayaka sheep. Asian J. Anim. Vet. Adv., 5: 120-127.

DAVIS G.H., DODDS K.G., WHEELER R. AND JAY N.P. (2001):Evidence that an imprinted gene on the $\mathrm{X}$ chromosome increases ovulation rate in sheep Biology of Reproduction.64 216-221.DAVIS G.H. (2004): Major genes affecting ovulation rate in sheep. Genet. Sel. Evol. 37, 1, 11-23.

DONEY J.M., GUNN R.G., HORAK F. (1982): Reproduction. In: Sheep and Goat Production, Coop, I.E. (Ed.). Elsevier Scientific, Amesterdam, pp: 57-80.

FORCADA F., ABECIA J.A. (2006): The effect of nutrition on the seasonality of reproduction in ewes. Reprod. Nutr. Dev. 46,355-365.

FUKUI Y., KOHNO H., OKABE K., KATSUKI S., YOSHIZAWA M., TOGARI T., WATANABE H, (2010): Factors affecting the fertility of ewes after intrauterine insemination with frozen-thawed semen during the non-breeding season. Journal of Reproduction and Development, 56, 4, 460-466.

GALLOWAY S.M., MCNATTY K.P., CAMBRIDGE L.M. (2000): Mutations in anoocyte-derived growth differentiation factor gene (BMP15) cause increased ovulation rate and infertility in a dosage-sensitive manner. Nature Genetics. 25, 279-283.

GARCIA M.R., AMSTALDEN M., WILLIAMS S.W., STANKO R.L. MORRISON AND C.D.( 2002): Serum leptin and its adipose gene expression during pubertal development, the estrous cycle and different seasons in cattle. J. Anim. Sci., 80: 2158-2167. 
GRANT W., MONTGOMERY S., GALLOWAY M., DAVIS G. H., MCNATTY K P. (2001): Genes controlling ovulation rate in sheep. Reproduction,121, 843-852. GUERRA J.C., THWAITES C. JEDEY. T.N, (1972): The effects of components of body weight on reproductive efficiency in the Merino ewe. J. Agric. Sci., 78: 245-249.

GUNN R.G, (1983): The Influence of Nutrition on the Reproductive Performance of Ewes. In: Sheep Production, Haresign, W. (Ed.). Butterworths, London, pp: 99110.

KOYCEGIZ F., EMSEN E., DIAZ C.A.G., KUTLUCA M, (2009): Effects of lambing season, lamb breed and ewe parity on production traits of fat tailed sheep and their lambs. J. Anim. Vet. Adv., 8: 195-198.

KOYUNCU M, (2005): Reproductive performance of kivircik ewes on accelerated lambing management. Pak. J. Biol. Sci., 8: 1499-1502.MADANI T., CHOUIA F. ABBAS K, (2009): Effect of oestrus synchronisation and body condition on reproduction of anoestrous ouled djellal ewes. Asian J. Anim. Vet. Adv., 4: 34-40. MULSANT P., LECERF F., FABRE S., SCHIBLER L., MONGET P., LANNELUC I., PISSELET C.,

RIQUET J., MONNIAUX D., CALLEBAUT I., CRIBIU E., THIMONIER J., TEYSSIER J., BODIN

L., COGNIE Y., ELSEN J.M, (2001): Mutation in bone morphogenetic protein receptor-1B is associated with increased ovulation rate in Booroola Merino ewes, Proc. Natl. Acad. Sci. 98, 5104-5109.

LASSOUED N., REKIK M., MAHOUACHI M., BEN H.M, (2004): The effect of nutrition prior to and during mating on ovulation rate, reproductive wastage, and lambing rate in three sheep breeds. Small Ruminant Research, 52, 1-2 , 117-125.

NOTTER, D. R. (2000): Effects of ewe age and season of lambing on prolificacy in U.S. Targhee, Suffolk, and Polypay sheep. Small Ruminant Res. 38:1-7.

OREGUI L.M., GABINA D., VICENTE M.S., BRAVO M.V. TREACHER T, (1997): Relationships between body condition score, body weight and internal fat deposits in Latxa ewes. Anim. Sci., 65: 63-69.

PAULENZ H., ADNOY T., FOSSEN O. H., SODERQUIST L., BERG K. A,(2002): Effect of deposition site and sperm number on the fertility of sheep inseminated with liquid semen. Veterinary Record, 150, 10,42 -49.

PETROVIĆ P.M, ŽUJOVIĆ M., D. NEGOVANOVICA, VLAHOVIC M. MEKIĆ C., D. ALAVANTIC (1997): Status and prospects of sheep breeding in Serbia. Biotechnology in Animal Husbandry. 3-4, 83-87.

PETROVIĆ P.M (2000): Genetics and Improvement of Sheep (monograph).Scientific Book, Belgrade, 365 pp.PETROVIĆ P.M, ŽUJOVIĆ M., D. NEGOVANOVIC, STRSOGLAVEC, S., RUZIC D. (2001): The importance of new selection methods in modern system of sheep breeding. Biotechnology in Animal Husbandry. 17, 159-167 
PETROVIC, P.M, ŽUJOVIĆ M., D. NEGOVANOVIC, MUSLIĆ RUZIC D., STRSOGLAVEC S. (2002): Some aspects of modern organizations selection procedures in sheep. Contemporary Agriculture.51, 3-4. 155-150.

PETROVIĆ M.P., RUŽIĆ-MUSLIĆ D., ŽUJOVIĆ M., MEKIĆ C,(2007): Genetic improvement of fertility in sheep by selection according to physiological parameters. Biotechnology in animal husbandry. 23, 311 - 321.

SCHWARTZ MW, WOODS SC, PORTED JR, SEELEY RJ \& BASKIN DG.(2000): Central nervous system control of food intake. Nature ,404,661-671. SOUZA C.J., MACDOUGALL C., CAMPBELL B.K., MCNEILLY A.S., BAIRD D.T. (2001): The Booroola $(\mathrm{FecB})$ phenotype is associated with a mutation in the bone morphogenetic receptor type 1 B (BMPR1B) gene. Journal of Endocrinology. 169, 1-6.

WILSON T., WU XI-YANG, JUENGEL J.L., ROSS I.K., LUMSDEN J.M., LORD E.A., DODDS K.G., WALLING G.A., MCEWAN J.C., O'CONNELL A.R., MCNATTY K.P., MONTGOMERY G.W. (2001): Highly prolific Booroola sheep have a mutation in the intracellular kinase domain of bone morphogenetic protein IB receptor (ALK- 6) that is expressed in both oocytes and granulosa cells, Biol. Reprod. 64 1225-1235.

ZYGOYIANNIS, D., STAMATARIS C., FRIGGENS N.C., DONEY J.M. EMMANS G.(1997): Estimation of the mature weight of three breeds of Greek sheep using condition scoring corrected for the effect of age. J. Anim. Sci., 64,147-153. 